Jadila: Journal of Development and Innovation

E-ISSN: 2723-6900

in Language and Literature Education

P-ISSN: 2745-9578

Publisher: Yayasan Karinosseff Muda Indonesia

Volume 2 Number 4

Page 378-391

\title{
Study of the Form and Meaning of Serwai Ethnic Spell Language
}

\author{
Ongky Gusfika \\ State Islamic Intitute of Bengkulu \\ gusfikaongky@gmail.com \\ Irwan Satria \\ satriairwan1971@mail.com \\ Vebbi Andra \\ vebbiandra@yahoo.com
}

\begin{abstract}
This study aims to determine the form and meaning of Serwai Ethnic spell language in Tebat Sibun Village, Talo Kecil District, Seluma Regency. In this research, the writers used descriptive research method with qualitative research type. From the results of this study, it can be concluded that those study discusses two problems, namely (1) What is the form of the Serawai Ethnic spell language in Tebat Sibun Village, Talo Kecil District, Seluma Regency (2) What is the meaning of serawai Ethnic mantra language in Tebat Sibun Village, Talo Kecil District, as long as. The results of the first problem research, it is known that there are five existence of the spell language of Serawai Ethnic in Tebat Sibun Village, Talo Kecil District, Seluma Regency (a) experience of spell language which contains elements of treatment (b) experience of spell language which contains elements of self-protection (c) Existence of spell language containing agricultural elements (d) existence of spell language containing elements of attracting women/pellets (e) existence of spell language containing elements of eliminating hatred. The results of the second problem research, it is known that the meaning of the language of the Serawai Ethnic in Tebat Sibun Village, Talo Kecil District, Seluma Regency, there are five meanings (a) the meaning of healing spell language (b) the meaning of self-protective spell language (c) the meaning of agricultural spell language (d) the meaning of language female charm spells/pellets (e) meaning of hate-killing spells.
\end{abstract}

Keywords: Existence mantra, Mantra of Meaning,Serawai Ethnic

\section{A. Introduction}

Regional literature is one of identities of an area. Regional literature contains cultural element that has important values. Because many things can evolve through regional literature starting from variety of languages to variety of cultures in an area. Regional literature is closely related to local culture. In which regional literature and local culture are part of national culture. 
Jadila: Journal of Development and Innovation

E-ISSN: 2723-6900

in Language and Literature Education

P-ISSN: 2745-9578

Publisher: Yayasan Karinosseff Muda Indonesia

Volume 2 Number 4

Page 378-391

The existence of national culture that is "Bhinneka Tungal Ika" can not be actualized without various forms of language and ethnicity in Indonesia.

Based on the existence of oral literature in the regions, especially in Republic of Indonesia until now it is still used by society. In which one of forms of oral literature in Bengkulu Province is oral literature in the form of a spell. Mantra oral literature is still widely believed and used in many instances especially among Serawai Ethnic community, in Tebat Sibun Village, Talo Kecil District, Seluma Regency.

According to Eman mantra oral literature can also be called old poetry, mantra belongs to fictional literature (prose and poetry), and non-fictional literature work is essay criticism. Prose covers legend, saga, genealogy or history and solace. And there is a repeating sound when reading it. When it is read, according to Zaidan et al, mantra will produce magical power, and feel solemn, magical, and trans. Mantra also emphasizes on a belief that is related to something magical, sacred, such as gods, spirits, stars, and the lord. When reading it is also not too loud, like reading poetry in general, mantra can be read softly with unclear pronunciation but can make magical power.

Mantra is mastered by certain people. People who master mantra is known as shaman in society. Shaman in certain society have very special role. That role can be seen in problems in the life od society related to necromacy, health, agriculture, magic, etc.

Among Serawai Ethnic community, especially in Tebat Sibun Village, Talo Kecil District, Seluma Regency, Bengkulu Province, society still use and believe with efficacy of spells. Mantra oral literature has grown and developed since ancient times and is passed down from generation to generation to the present generation. Mantras for the people of the Serawai Ethnic are often referred as ancient medicine (ulama medicine) and as part of a self-protection tool (body-strengthening jejampian). One form of mantra that is very well known in Serawai Ethnic community is a healing spell, farming, and self-protection spell.

Healing mantra oral literature is used by Serawai society for special purpose, that is to heal various deseases still with mantra and used by Serawai ethnic society in Seluma Regency until now. However, healing mantra is very little in demand because there have been many modern medicines from health sciences, and who learn mantra are very few because there is no 
Jadila: Journal of Development and Innovation

E-ISSN: 2723-6900

in Language and Literature Education

P-ISSN: 2745-9578

Publisher: Yayasan Karinosseff Muda Indonesia

Volume 2 Number 4

Page 378-391

interest from young generations to preserve this oral literature. Farming spell is used to protect plants from disturbing pests and to get satisfactory agricutural results, meanwhile self-protection spell is used to protect self from bad things, for example while traveling on a trip asking for selfsafety to the destination.

Mantra in Serawai Ethnic society is part of language, surely must be protected. Considering the importance of function of mantra as part of language, so mantra needs to get attention so that it gets preserved. It is done to defend the mantra from extinction. That way it is hoped that the existing mantra can be passed down to postery.

In the early observation done on September 302020 in Tebat Sibun Village, Talo Kecil District, Seluma Regency. The first thing done were observation and interview with local village government to do research. The result of interview with village society, mantra is still widely used by Tebat Sibun village society, such as healing spell, farming spell, and self-protection spell, love spell, and other kinds of mantra. It is similar with the result of interview with informant. Determining informant and looking for information who master about mantra as well as wanting to get real and deep information about mantra. This research used observation interview, and documentation technique with informant directly.

Based on the explanation above, so the author is really interested to do research and study about mantra oral literature entitled "Study of The Form and Meaning of Spell Language of Serawai Ethnic in Tebat Sibun Village, Talo Kecil District, Seluma Regency, Bengkulu Province".

\section{B. Research Method}

The form of research that the author used is a field research where the research is in the form of empirical studies to use theories regarding to the process of occurrence and regarding to the process of qualitative research in the field. In this research, the writer used descriptive research method with qualitative research type.

Qualitative research is a form of research based on positivism philosophy, used to research in the condition of natural object, (the opposite is experiment) in which a researcher is the key instrument, data collection technique was done with triangulation (combination), 
Jadila: Journal of Development and Innovation

E-ISSN: 2723-6900

in Language and Literature Education

P-ISSN: 2745-9578

Publisher: Yayasan Karinosseff Muda Indonesia

Volume 2 Number 4

Page 378-391

inductive/qualitative data analysis, and the result of qualitative research is more emphasized on meaning than on generalization. Qualitative research also aims to develop sensitivity concept on problem faced, to explain reality that is related to searching of grounded theory and to develop understanding on one or more phenomena faced.

According to Mcmillan dan Schumacher, in qualitative research researcher is involved in the situation of the phenomenon being studied. In this research, the researcher also assumed social interaction function by means of an interactive neutral-traditional and active interactive approach.

Meanwhile descriptive research method is a method that gives real depiction. According to Djajasudarma descriptive research aims to give potrayal factually on investigated things. Sugiyono also says that descriptive method is a method that guides researcher to explore and describe social situation to be researched thoroughly, broadly, and deeply.

The subject of this research was shaman in Tebat Sibun Village, Talo Kecil District, Seluma Regency. The subject is the one who will give information about situation of social phenomena that occured on the field. The subject in this research was an informant. Moleong says that informant is a person in research background that is utilized to give information about situation and condition of research background. According to Spradley the way to determine subject who can be source of information is a person who can be contacted easily and gives permisson easily to do research. The chosen informant is the one who seems able to give information, related to object of research and will facilitate the process of research.

Data observation technique used by the researcher in collecting data in this research were observation, interview, and documentation. Researcher used triangulation technique data resource (data), triangulation technique, and time triangulation to test data validity that is related to research problem investigated by the researcher. Data used in this research did not wait until complete data was collected and then analyze it. The researcher since the beginning read and analyzed the collected data, either interview transcript, field note, documentation or other materials critically and analytically gave and did credibility test or validity check continously.

\section{Result and Discussion}


Jadila: Journal of Development and Innovation

E-ISSN: 2723-6900

in Language and Literature Education

P-ISSN: 2745-9578

Publisher: Yayasan Karinosseff Muda Indonesia

Volume 2 Number 4

Page 378-391

\section{Result}

a. The forms of Serawai Tribe's spell language in Tebat Sibun Village, Talo Kecil District, Seluma Regency

\section{1) Healing Spell}

Healing spell is oftenly used by society for cure and called ancient medicine (ulama medicine). Healing spell is used by Serawai Ethnic society for particular reason to cure various kinds of deseases. Healing with mantra still survives and is used by Serawai Etnic society in Tebat Sibun Village, Talo Kecil District, Seluma Regency. The forms of healing mantra as follow:

Data of Mantra 1Jampi Jemo Nyemulung Malam dengan Siang/People Crying Day and Night Spell

Bismillah Hirohma nirohim

Keluhu wakendi

Qul huallah uhad

Qun pasah kuhun

Kendira Allah

Abadah $2 x$

Kato Allah

(Sarim)

Indonesian translation :

Bismillah hirohman nirohim

Keluhu wakendi

Qul huwallahu uhad

Qun pasa kuhum

Kehendak Allah (Allah's will)

Ibadah 2x (prayer 2x)

Kata Allah (Allah says)

Spell above belongs to form of healing mantra because that spell asks for cure for people

disturbed by spirit or ghost because there is a word implied in the mantra saying "qun pasa kuhum" means humans' trait or character do not punish his body and no place to ask except from Allah for cure for sick people.

\section{2) Self Protection Spell}


Jadila: Journal of Development and Innovation

E-ISSN: 2723-6900

in Language and Literature Education

P-ISSN: 2745-9578

Publisher: Yayasan Karinosseff Muda Indonesia

Volume 2 Number 4

Page 378-391

Self protection spell is used to protect one's self from bad things, for example when traveling on a trip asking for self safety. The form of self protection spell that is oftenly used by Tebat Sibun Village, Talo Kecil District, Seluma Regency as follow:

\section{DM 2 Jampi Gajah Biring/Gajah Biring Spell}

Gajah biring Gajah meninting

Gajah putih sungsang namonyo

Aku bepaud dari ekornya

Aku betekit dari jengkunyo

Tunduk berangkat anak langsung

Anak harimau bejalan-jalan

(Suminia)

Indonesian translation:

Gajah biring Gajah meninting

Gajah putih sunsang namanya (Gajah Putuh the name is sunsang)

Aku berpegang pada ekornya (I hold on to the tail)

Aku berpijak dari lututnya (I stand on his knees)

Tunduk berangkat anak langsung

Anak Harimau berjalan-jalan (tiger cub walk around)

Spell above belongs to form of self protection spell because the spell asks for self protection because there is a word implied in the spell saying "Gajah biring Gajah meninting dan anak Harimau berjalan-jalan" means that it represents a powerful force in one's self who use this spell. Elephant is a powerful animal meanwhile tiger is king of the jungle when it walks and travels no one dares to bother it.

\section{3) Agricultural Spell}

Agricultural spell is used to protect plants from disturbing pests to get satisfying agricultural products. The form of spell that is oftenly used by society of Tebat Sibun Village, Talo Kecil District, Seluma Regency as follow:

\section{DM 3 Jampi Piangang/Agricultural Spell}

\section{U...t Piangang Piangut $3 x$}

Datang kisak di berang sano lautan

Nido buliah engkau menyiso

Barang tanaman aku

Kembali engkau keberang sano lautan

Itu tempat istana engkau

Berkat kalimat

Lailah hakilaulah 
Jadila: Journal of Development and Innovation

E-ISSN: 2723-6900

in Language and Literature Education

P-ISSN: 2745-9578

Publisher: Yayasan Karinosseff Muda Indonesia

Volume 2 Number 4

(Ardan J)

Page 378-391

Indonesian translation:

U....t Piangang Piangut $3 \mathrm{x}$

Datang dari seberang lautan (coming from across the ocean)

Tidak boleh menyiksa (can not torture)

Tanaman aku (my plant)

Kembalilah engkau kesebrang sana lautan (come back to the other side of the sea)

Itu tempat istana engkau (that place is your palace)

Berkat kalimat lailah hailaulah (because of sentence laillahaillaulah)

Spell above belongs to form of agricultural spell because the spell asks for satisfying agricultural product and protect from disturbing pests because there is a word implied in this spell saying "tanaman aku” means do not disturb farm that I plant.

\section{4) Female Charm Spells/Pellets}

Female charm spells/pellets is still used among young people who learn it. The form of female charm spells/pellets that is oftenly used in Tebat Sibun Village, Talo Kecil District, Seluma Regency as follow:

\section{DM 4 Jampi Dua Siriah/Dua Sirih Spell}

Siriahku selarin kuning

Jagan kelayak kelayuan

Kalu kelayak kelayuan

Gilo siang gilo lamamalam

Gilo adak berenti agi

Belum besuo pado aku

Belum beradu ati linjang

Labesuo pado aku baru begadu ati linjang

Berkat keduo siriah aku

Kato Allah

(Sasrim)

Indonesian translation:

Sirihku warna kuning (my betel is yellow)

Jangan kelayak kelayun (do not kelayak kelayun)

Gila siang gila waktu malam (being crazy in day being crazy at night)

Gila tidak berhenti lagi (being crazy will not stop anymore)

Belum bertemu padaku (have not met me)

Belum berhenti hati rindu (the heart has not stopped missing)

Sudah bertemu aku barulah sembuh hati rindu (if she has met me then her heart will stop missing)

Karna kedua sirih aku (because of my two ketels) 
Jadila: Journal of Development and Innovation

E-ISSN: 2723-6900

in Language and Literature Education

P-ISSN: 2745-9578

Publisher: Yayasan Karinosseff Muda Indonesia

Volume 2 Number 4

Kata Allah (Allah says)

Spell above belongs to form of female charm spells/pellets because this spell wants a girl that he wants to love because there is a word implied in this spell saying "belum bertemu padaku" means a woman that I read this spell will get crazy about me and will never stop missing me because she has not met me yet.

\section{5) Hate-Killing Spell}

Hate-killing spell makes people who dislike someone and can love or not liking to liking. The form of spell that is oftenly used by society of Tebat Sibun Village as follow:

\section{DM 5 Jampi Rasa Benci Alang-Alang/Hate Reed Spell}

Alang-alang sekito besar

Alang tutup sekito rayo

Bisu bumi bisulah langit

Bisulah ati budak sianu

Tepandang pada cayo aku

Kato Allah

(Lahiyah)

Indonesian translation:

Alang-alang begitu besar (Alang-alang as big as us)

Alang tertutup sejagat raya (the world mute the sky mute)

Bisu bumi bisulah langit bisulah hati orang itu (mute that girl's heart)

Terpandang pada aku (look at my light)

Terdengar pada suara aku (listen to my voice)

Kata Allah (Allah says)

Spell above belongs to the form of hate-killing spell because the spell asks the people who hate or dislike with who read this spell no longer hate because there are words implied in the spell saying "bisu bumi bisulah langit bisulah hati orang itu" means asking for muting the heart and the sky when people hate me and then he no longer hates me.

b. The Meanings of Serawai Tribe's spell language in Tebat Sibun Village, Talo Kecil District, Seluma Regency

DM 1 Jampi Jemo Nyemulung Malam dengan Siang/ People Crying Day and Night Spell

Bismillah hirohman nirohim

Keluhu wakendi

Qul huwallahu had

Qun pasah kuhun 
Jadila: Journal of Development and Innovation

E-ISSN: 2723-6900

in Language and Literature Education

P-ISSN: 2745-9578

Publisher: Yayasan Karinosseff Muda Indonesia

Volume 2 Number 4

Kendira Allah

Page 378-391

Abadah $2 x$

Kato Allah

(Sarim)

Indonesian translation:

Bismillah hirohman nirohim

Keluhu wakendi

Qul huwallahu ahad

Qun pasa kuhum

Kehendak Allah (Allah's will)

Ibadah 2x (prayer 2x)

Kata Allah (Allah says)

"Bismillah hirohman nirohim" (Bismillah hirohman nirohim) means in the name of Allah, the Most Gracious, the Most Merciful "kluhu wakendi" (qul hu wakendi) means say that he is the one and only god, there is no place to ask for healing except to him who can heal and the great almighty "qun pasah kuhum” (qun pasah kuhum) means humans' character do not punish his body "kendira Alla" (Allah's will) means everything that happens by the will of Allah "abadah 2x" (prayer 2x) means act or statement of devotion to Allah "kato Allah" (Allah says) means by Allah's permission.

The following is the text of the result of research on informant Sarim, Sarim said this spell is used for babies and children who are still underage because this spell is used to cure people who are disturbed by spirit or ghost. The way to use this spell also uses media of orange and it is read to sliced orange with 3 slices and read the spell then put in water and wash in face after that in people's crown who get disturbed.

\section{DM 2 Jampi Gajah Biring/Gajah Biring Spell}

Gajah biring Gajah meninting

Gajah putih sungsang namonyo

Aku bepaud dari ekornya

Aku betekit dari jengkunyo

Tunduk berangkat anak langsung

Anak harimau bejalan-jalan

(Suminia)

“Gajah Biring gajah Meninting” (Gaja Biring Gajah Meninting) means calling ghost for help "Gajah putih sunsang namonyo" (Gaja Putuh the name is sunsang) also means calling ghost 
Jadila: Journal of Development and Innovation

E-ISSN: 2723-6900

in Language and Literature Education

P-ISSN: 2745-9578

Publisher: Yayasan Karinosseff Muda Indonesia

Volume 2 Number 4

Page 378-391

"aku bepaut dari ekornya" (I hold on to the tail) means I ask for a favor and I am behind it "aku betekit dari jengkunyo" (I stand on his knees) means help me to protect myself "tunduk berangkat anak langsung" (tunduk berangkat anak langsung) means make them submit to me "anak Harimau bejalan-jalan" (tiger cub walk around) means as if they saw tiger cub and no one dares to disturb.

The following is the text of the result of research on informant Suminia, Suminia said this protecting spell is used when we want to go outside or travel so that we are protected from bad things such as getting disturbed while traveling. The way to use this spell is to read it when we want to go outside.

\section{DM 3 Jampi Piangang/Piangang Spell}

U...t Piangang Piangut $3 x$

Datang kisak di berang sano lautan

Nido buliah engkau menyiso

Barang tanaman aku

Kembali engkau keberang sano lautan

Itu tempat istana engkau

Berkat kalimat

Lailah hakilaulah

(Ardan J)

"U...t Piangang Piangut 3x" (U...t piangang piangut $3 \mathrm{x}$ ) means calling the name of pests which disturb plants/agriculture three times in a row "datang kisak disebrang sano lautan" (coming from across the ocean) means piangang comes all the way from across the ocean "nido buliah engkau menyiso" (can not torture) means do not disturb that plant "barang tanaman aku" (my plant) means do not disturb plants that I plant "kembalilah engkau kesebrang sano lautan" (come back to the other side of the sea) means repel pianggang that disturb my plant and go back to where you are from "itu tempat istana engkau" (that place is your palace) means go back to your origin and it is your place and never return "berkat kalimat laillahailaullah" (because of sentence laillahaillaulah) means by Allah's permission.

The following is the text of the result of research on informant Ardan J, Ardan J said that this agricultural spell is used when plants are disturbed by pest pianggang, the impact of pianggang can make worse agricultural production or less satisfying. The way to use this spell is 
Jadila: Journal of Development and Innovation

E-ISSN: 2723-6900

in Language and Literature Education

P-ISSN: 2745-9578

Publisher: Yayasan Karinosseff Muda Indonesia

Volume 2 Number 4

Page 378-391

by cathching 5 pianggang and read read this spell to pianggang that is catched after that it is released again.

\section{DM 4 Jampi Duo Siriah/Dua Sirih Spell}

Siriahku selarin kuning

Jagan kelayak kelayuan

Kalu kelayak kelayuan

Gilo siang gilo lamamalam

Gilo adak berenti agi

Belum besuo pado aku

Belum beradu ati linjang

Labesuo pado aku baru begadu ati linjang

Berkat keduo siriah aku

Kato Allah

(Sasrim)

"Sirihku selarin kuning" (my betel is yellow) means two yellow betels already "jagan kelayak kelayun" (do not kelayak kelayun) means no direction "gilo siang gilo lamalam" (being crazy in day being crazy at night) means no matter day or night will be crazy "gilo adak berenti lagi" (being crazy will not stop anymore) means will never stop being crazy "belum besuo pado $a k u$ " (have not met me) means if she has not met me yet she will not have any direction "belum beradu ati linjang" (the heart has not stopped missing) means she will always thinks and will not stop missing me "labesuo pado aku baru begadu ati linjang" (if she has met me then her heart will stop missing) means if she has met me then her missing heart will be cured "berkat keduo siriah aku" (because of my two ketels) means because she gets my 2 betels in me "kato Allah" (Allah says) by Allah's permission.

The following is the text of the result of research on informant Sarim, Sarim said this female charm spell is similar to other female charm spells, wanting to attract woman that he wants to love when she does this spell the woman that he will love will have no direction except direction to love him. The way to use this spell is by preparing two betels with yellow leaves already and read the spell.

\section{DM 5 Jampi Raso Benci Alang-Alang/Feeling Hate Alang-Alang Spell}

Alang-alang sekito besar

Alang tutup sekito rayo

Bisu bumi bisulah langit 
Jadila: Journal of Development and Innovation

in Language and Literature Education

Publisher: Yayasan Karinosseff Muda Indonesia

Bisulah ati budak sianu

Tepandang pada cayo aku

Kato Allah

(Lahiyah)
E-ISSN: 2723-6900

P-ISSN: 2745-9578

Volume 2 Number 4

Page 378-391

"Alang-alang sekito besar" (Alang-alang as big as us) means asking from the greatest ruler "bisu bumi bisulah langit" (the world mute the sky mute) means no one can speak "bisulah ati budak sianu" (mute that girl's heart) means that woman's heart dies and can not speak anymore because I have locked "tepandang pada cayo aku" (look at my light) means when she sees me "tedengar pado suaro aku" (listen to my voice) means when she hears my voice "kato Allah” (Allah says) by Allah's permission.

The following is the text of the result of research on informant Lahiyah, Lahiya said similarly this killing-hate spell with other killing-hate spells want to make people who hate to love for instance in politics etc. the way to use it just by reading this spell and begging for bless so that it will be potent or it will happen.

\section{Discussion}

According to Danandjaja (1987) and other literature experts in general agree that the early form of indonesian poetry is spell. According to Rusyana (1970) in regional old literature, there are various analogies to magical things, can produce magical power. Analogy used mathces its function, for example healing spell, pellet to attract someone, asihan attraction to someone, witchcraft to harm people, jangjawokan as prayer for asking for desired things. In the group of old indonesian literature, those various kinds are called spell.

From the results of this research, it is known that there are five forms of the spell language of Serawai Ethnic in Tebat Sibun Village, Talo Kecil District, Seluma Regency (a) form of spell language which contains elements of treatment (b) form of spell language which contains elements of self-protection (c) form of spell language containing agricultural elements (d) form of spell language containing elements of attracting women/pellets (e) form of spell language containing elements of eliminating hatred.

According to Tarigan (1985) semantics that is initially from Greece, contain meaning to signify or to give meaning. A technical term, semantics contains a definition "the study of 
Jadila: Journal of Development and Innovation

E-ISSN: 2723-6900

in Language and Literature Education

P-ISSN: 2745-9578

Publisher: Yayasan Karinosseff Muda Indonesia

Volume 2 Number 4

Page 378-391

meaning". Assuming that meaning has become part of language, meaning of semantics is part of linguistics. Semantics analyzes symbols or signs that express meaning, relationship of meaning to one another, and its effect on human being and society. Next, Aminuddin (1988) states that meaning coming from word turns out to have close relationship with: (1) socio-cultural system and referenced external reality, (2) user, and (3) situational social context in using. According to Grice and Bolinger meaning is relationship between language and external world that has been mutually agreed by language users so that can be understood each other.

From the results of the research, it is known that the meaning of the language of the Serawai Ethnic in Tebat Sibun Village, Talo Kecil District, Seluma Regency, there are five meanings (a) the meaning of healing spell language (b) the meaning of self-protective spell language (c) the meaning of agricultural spell language (d) the meaning of language female charm spells/pellets (e) meaning of hate-killing spells.

\section{Conclusion}

1. From research, it is known that there are five forms of the spell language of Serawai Ethnic in Tebat Sibun Village, Talo Kecil District, Seluma Regency (a) form of spell language which contains elements of treatment (b) form of spell language which contains elements of selfprotection (c) form of spell language containing agricultural elements (d) form of spell language containing elements of attracting women/pellets (e) form of spell language containing elements of eliminating hatred.

2. From research, it is known that the meaning of the language of the Serawai Ethnic in Tebat Sibun Village, Talo Kecil District, Seluma Regency, there are five meanings (a) the meaning of healing spell language (b) the meaning of self-protective spell language (c) the meaning of agricultural spell language (d) the meaning of language female charm spells/pellets (e) meaning of hate-killing spell,

\section{References}

Adriyetti, A. (2013). Sastra Lisan Indonesia. Yogyakarta: Andi Offset.

Aminudin. (1988). Semantik Pengantar Studi Tentang Makna. Bandung: Sinar Baru Offset. 
Jadila: Journal of Development and Innovation

E-ISSN: 2723-6900

in Language and Literature Education

P-ISSN: 2745-9578

Publisher: Yayasan Karinosseff Muda Indonesia

Volume 2 Number 4

Page 378-391

Ai, S.N. (2015). Mantra Pengasihan: Telaah Struktur, Konteks Penuturan, Fungsi, dan Proses Pewarisannya. Riksa Bahasa, vol. 1 no. 2 (752-17773-1-PB.pdf, 28 Desember 2020).

Chaer, A., dan Agustina, L. (2010). Sosiolingustik Perkenalan Awal Edisi Revisi.Jakarta: Rineka Cipta.

Dede, H. (2016). Struktur, Bentuk, dan Fungsi Mantra Abal. Balai Bahasa Kalimantan Selatan, $4(2), 1$.

Dini, F. (2018). Mantra Pengobatan dalam Upacara Penyembuhan terhadap Karakteristik Masyarakat Lebak Banten. Jurnal Pendidikan Bahasa dan Sastra Indonesia, 12(1), 2.

Edi, S., dan Mulyanto. (2017). Bentuk dan Fungsi Teks Mantra. Balai Bahasa Daerah Istimewa Yogyakarta. 9(2),1.

Gunawan, I. (2017). Metode Penelitian Kualitatif Teori dan Praktik. Jakarta: Bumi Aksara.

Hajaratul, A., dan Nurhayaty. (2018). The Use of Mantra in The Tradition of Maitai Allo Macoa in Onglo People Campalagian Subdistrict Polman Regency: A Review of The Semiotics. Ilmu Budaya, 6(1), 2.

Iskandar. (2008). Metodologi Penelitian Pendidikan dan Sosial, Kuantitatif dan Kualitatif. Jakarta: Gaung Persada Press.

Parera, J.D. (2004). Teori Semantik Edisi Kedua. Jakarta: Erlangga.

Khaerudin., \& Kurniawan. (2018). Metodologi Penelitian Bahasa dan Sastra Indonesia. Bandung: Pustaka Setia.

Lexsi, J. M. (2017). Metodologi Penelitian Kualitatif Edisi Revisi. Bandung: Remaja Rosdakarya.

Muhammad, H. (2016). Bentuk Fungsi, dan Makna Mantra Ritual Upacara Kasambu Masyarakat Muna di Kecamatan Katobu Kabupaten Muna. Pendidikan Bahasa dan Sastravol. 1(2), 1. 